\title{
Cultural Heritage and Cultural Potential: The Use of Cultural Heritage on the Example of an Ethnographic Group
}

\author{
Ladislav Lenovský - Lukáš Kurajda
}

Prof. PhDr. Ladislav Lenovský, PhD.

University of Ss. Cyril and Methodius in Trnava

Faculty of Arts

Department of Ethnology and World Studies

Nám. J. Herdu 2

91701 Trnava

Slovak Republic

e-mail: ladislav.lenovsky@ucm.sk

ORCID: 0000-0003-3059-5036

Mgr. Lukáš Kurajda, PhD.

University of Ss. Cyril and Methodius in Trnava

Faculty of Arts

Nám. J. Herdu 2

91701 Trnava

Slovak Republic

e-mail: lukas.kurajda@ucm.sk

ORCID: 0000-0002-0975-2490

Muzeológia a kultúrne dedičstvo, 2022, 10:1:79-104

DOI: $10.46284 / \mathrm{mkd} .2022 .10 .1 .5$

\section{Cultural Heritage and Cultural Potential: The Use of Cultural Heritage on the Example of an Ethnographic} Group

The formation and use of the cultural heritage and identity of local communities is a result of historical development and current opportunities and needs. Cultural heritage becomes a part of the cultural potential as a system. In Cajkov, the most representative village of the Slovak Chilejkar people, there is a system of using the established concept of local cultural heritage through cultural events (several of which are closely connected in terms of organisation and visitors) implemented by local human resources structured into local organisations and institutions, which are relatively diverse but have an internal logic. Some events have an old tradition; others originated and became "traditional" only a few years ago.

The outlined system existing in a municipality with less than 1000 inhabitants reflects the degree of functioning of the local community. It is conditioned by cohesion, hierarchy, the self-confidence of members and appropriate economic conditions. For seniors, besides routine and tradition, the essential activating element is the social dimension - being socially active means meeting others, spending time with peers and eliminating loneliness. It is also an important identity creator in the socialisation, education and especially the upbringing of children and youth.

Keywords: cultural heritage, cultural potential, ethnographic group, Chilejkars, Čajkov

\section{Introduction}

Cultural heritage is a relatively well-discussed phenomenon in several social and scientific disciplines and social practices. The relevant scientific disciplines carry out cultural heritage 
research to address their objects of interest (for example, anthropology and man, ${ }^{1}$ ethnology and ethnic collectivities/processes, history and past, culturology and culture, or geography and cultural landscape). Such an interest is legitimate but partial. Cultural heritage is contextually reduced to only its discipline-relevant part (for example, ethnology and traditional culture, art history and art, architecture and architectural styles, museology and museum and gallery collections, archaeology and archaeological sites and excavations). A holistic grasp of cultural heritage comes into consideration, perhaps, only in the context of heritology, which is the only discipline primarily interested in cultural heritage. However, the question of defining cultural heritage is always conditioned by the definition of culture.

In the broadest sense, culture features mainly in anthropology (as a universal attribute of humankind/humanity) and culturology (as a universally or constructively understood phenomenon of world culture). In connection with such an understanding of culture, cultural heritage (humanity or world) is also defined. Culture in the distributive understanding (as a way of life and thinking of a particular group of people in a particular time and space) formulates cultural heritage as a specific "prefabricated" structure of the use ${ }^{2}$ of cultural elements, complexes and phenomena from the past. This process may be realised by tradition - as an automated, sometimes unconscious continuity of intergenerational transmission resulting from the anthropological nature of cultural heritage. (This seems to be a better term for the "use" of cultural heritage.) Alternatively, it is a sophisticated deliberate treatment of what is called a cultural heritage in order to achieve a clearly identified and expected profit, resulting from a preference for the axiological nature of culture and cultural heritage. (Here is a better notion of the "utilising" of cultural heritage.) Such thinking makes it possible to see traditions in a particular community as a tool for self-identification and representation. Also, as a significant part of the community's cultural, social or socio-cultural potential or capital, or even a finished product, it can be viewed as a tool of profit.

How does each of these two perspectives arise? What projection, penetration and mutual relationship do they have in a particular socio-cultural reality?

The paper aims to answer these questions on the example of cultural development, creating the concept of cultural heritage, its use and usability as cultural potential today in the local community of the inhabitants of Čajov, the most representative locality of the ethnographic group of the Chilejkars.

The knowledge is obtained by studying scientific and professional resources about the locality, mostly of ethnographic character, which are the result of previous research by the Tekov Museum in Levice (based in the district town of Levice), supplemented and updated by the field research of students and staff of the Department of Ethnology and World Studies conducted between 2017-2020. The paper uses the synchronous method to clarify the development and current state of selected traditional cultural phenomena today formulated by the local society into cultural heritage. Subsequently, the use of cultural heritage is analysed and interpreted through the first phase of the methodology for evaluating cultural potential

\footnotetext{
${ }^{1}$ Historical definitions of culture, as one of the eight groups of definitions of culture, into which A. Kroeber and C. Kluckhohn divided 164 definitions of culture in 1952, emphasise the processes of social transmission, culture as a social heritage, cultural traditions, inherited artifacts or summary social heritage. (GAŽOVÁ, Viera. Úvod do kulturológie. Bratislava: FF UK, 2009, pp.16-17.)

${ }^{2}$ The relevance of the term is determined by whether it is a descriptive-structural or a procedural concept of cultural heritage.
} 
- cultural mapping. ${ }^{3}$ Since the presented paper focuses on the existing system of cultural potential and the relevant phenomena of the local cultural heritage in it, the second phase evaluation - is secondary, and its processing is partial. Finally, the article outlines the cultural network of the Cajkov locality within/through which the most significant part of its cultural heritage exists today.

The cultural traditions and heritage of the ethnographic group of the Chilejkars represent an important part of the traditional culture and heritage of Slovakia. In some areas of the material and spiritual culture of Slovakia, the culture of the Chilejkars is one of the most significant and representative examples.

\section{Cultural heritage}

Previous theoretical research in the field of cultural heritage over the past decades has resulted in heritage studies as a multidisciplinary platform/paradigm. There has been a shift from descriptive, enumerative and classification concepts to procedural and universalist concepts (static to dynamic). ${ }^{4}$ As one of the intensive lines of argument of heritage studies, this tendency currently resonates as critical heritage. It could rescue research and also redefine existing interpretations. Here, research of cultural heritage is research into the process of its creation, perception, survival and the transmission of tangible and intangible cultural forms not only as artifacts but also as functional meanings and symbols. In heritage as a process, cultural heritage acts as a social phenomenon realised mainly through cultural memory, identity, social conflict, social space and tradition ${ }^{5}$ and as a tool for socio-economic development through cultural (and more broadly) creative industries.

Cultural heritage in the (most general) anthropological understanding represents all cultural phenomena preserved by intergenerational transmission, ${ }^{6}$ elements and complexes usually identified and interpreted through (as) components of material, social and spiritual culture, which its bearers (as stereotypes) use as tools and strategies, or as exclusive characters, activities and ideas. Cultural heritage is defined in terms of content and development precisely by the process of tradition. ${ }^{7}$ Without it, human communities could only be perceived on a biologicalreproductive basis as packs, flocks or herds. Cultural heritage is a tool for creating (and seeing) human communities as relatively organised social structures operating according to their own rules, ideas and activities.

The primary grasp of cultural heritage characterises the axiological approach as a value (artistic, historical-documentary, cultural-social, economic et cetera). It is done either by preferring those parts of it that the bearers or researchers perceive as valuable (the most valuable) or by interpreting the cultural heritage precisely through examining its value and use. An inseparable essence and result of using the constructed/prefabricated concept of cultural heritage in the public sphere is the pathos and awe presented (and usually actually felt) by the

\footnotetext{
${ }^{3}$ LENOVSKÝ, Ladislav et al. Hodnotiaci model kultúrneho potenciálu. Nitra: UKF v Nitre, 2014.

${ }^{4}$ SMITH, Laurajane. The Uses of Heritage. London and New York: Routledge, 2006; and HARRISON, Rodney. Heritage: Critical approaches. London and New York: Routledge, 2013.

${ }^{5}$ KRIŠKOVÁ, Zdena. The Use of the Socio-Cultural Potential of Local Societies through the Presentation of Cultural Specificities. In: Slovak Ethnology, 67 (3), 2019, p. 313.

${ }^{6}$ MURÍN, Ivan. Generational transmission in local culture: An exploration of European research drivers in Central Slovakia. In: Anthropological Journal of European Cultures, 25 (2), 2016, pp. 57-72.

${ }^{7}$ Not in terms of traditional culture, but rather transmitted culture.
} 
participants of this process. A value (or its image) is proven/created by constant "rewriting" in such a discourse.

\section{Cultural potential}

The use of cultural heritage is focused primarily on gaining profit of its current (and potential) bearers, performers and consumers. Cultural heritage contexts are currently contracted either in connection with its inward action - as an identity-forming factor of its bearers, or outwardly, as localisation preconditions for tourism development. Cultural or cultural-historical localisation assumptions are an integral part of the overall system in tourism. Knowing how to use cultural potential, its transformation into cultural capital, and the product's subsequent sale is the competence to successfully implement this transformation. The result is experience, knowledge and emotion in consumers - tourists, locals and visitors, perceived as profit. Within tourism, it is a matter of attracting tourists and keeping them in place long enough for them to use the offered services as much as possible and satisfy their needs with the aim of their future return. It can lead to economic benefits for service providers.

The cultural potential is the sum of the most diverse cultural values used for any profit. With adequate cultural management, it changes into cultural capital. Profit occurs when the cultural potential is transformed into cultural capital by commodification and its being sold as a commodity.

If a piece of cultural heritage adapted into a product becomes a marketing product, an "entrepreneurial" strategy can also occur through unconscious, acculturated management. If any product becomes part of the market, it responds within the supply-demand framework. As demand increases, so does supply (and the value of goods); as demand decreases, so does supply (and the value of goods). These processes also determine and model the structure and content of cultural heritage. Changes and interventions based on economic strategy change the structure of cultural heritage depending on the needs of the market. Furthermore, this is about economic profit and social, emotional or entertainment-relaxation profit.

Following Krišková, ${ }^{8}$ we can state that the cultural potential is the hidden and unused capacities of the cultural capital - tangible or intangible - of non/formalised cultural heritage. The valorisation and visibility of unused heritage create an offer for the arrival of economic capital in the form of the preparation of products for touristic, educational, artistic, recreational and leisure activities carried out by institutions and organisations as part of the creative industries. At the same time, it occurs in the creation/maintenance of local identity, genius loci and local patriotism. "The identification of the inhabitants with their locality, the interest in it which is also built through local cultural values - leads to a greater willingness to participate in its development, to engage in cooperation, to participate in local activities." It also contributes to the maintaining/creating of social capital, interpersonal ties and communities.

Cultural mapping is used to reveal and document cultural values (cultural resources). The terms cultural value, cultural resources and cultural potential can be understood as synonyms in this case. Cultural mapping is a fundamental precondition for the transformation of potential into capital. It aims to identify (recognise, determine and describe) these sources, classify them

\footnotetext{
${ }^{8}$ KRIŠKOVÁ, Zdena. Kultúrne dedičstvo a pamätové inštitúcie. Krakov: Spolok Slovákov v Pol'sku, 2017, pp. $22-23$.

9 JANTO, Juraj. Kultúrny a sociálny kapitál lokality ako prostriedok miestneho rozvoja. In: Muzeológia a kultúrne dedičstvo = Museology and Cultural Heritage $:$ vedecký recenzovaný časopis : peer-reviewed scholarly journal, 1 (1), 2013 , p. 94.
} 
(divide into categories and classes) and then evaluate them quantitatively and qualitatively. It is a taxonomy of cultural resources. ${ }^{10}$

Cultural potential consists of: a) culture (and the cultural heritage within it); b) cultural organisations and institutions; c) cultural events and cultural products; d) cultural infrastructure; and e) human resources (individual professions and cultural/creative sector). ${ }^{11}$ Each of these categories has its evaluation criteria, resulting from the different nature of the category. During mapping and evaluation, it is necessary to obtain specific information about each element/ complex/phenomenon. The status assessment period is the present. The research object can be a community, local society, region, state or ethnic, ethnographic, religious or any other defined group. ${ }^{12}$ In the system of mapping, identification, and documentation of cultural resources, material (tangible) elements (resource mapping) are more often reflected. However, there are also many more identifiable and measurable aspects of an intangible nature (genius loci, collective values, identity and attitudes, human resources, symbols, signs, standard of living, local ties or neighbourly relations). Their presence is often much more significant than the existence of tangible elements. Their mapping, identification and detection is a much more sophisticated system (community identity mapping) ${ }^{13}$

There are pulsating and conditional ties and relationships between the mentioned cultural potential components, creating a cultural network. These bonds can exist naturally, but they can also be formed. The more sophisticated and elaborate the relationships, the more space opens up to exploit the potential. Intensive relationships between the various components support the creation of an effective tool for the use of cultural heritage - cultural clusters and networks.

Cultural mapping and evaluation create an image/map of cultural potential in the researched locality/community. Cross-sectionally, it concerns various areas of culture (educational, museum, gallery and theatre activities, activities in the field of audio-visuals, the protection of monuments et cetera), as well as other areas with cultural representation (municipal policy and economy, strategic presentation of localities and regions, social life, recreation, tourism et cetera). Together they form an inspiration and knowledge base and delimit the implementation framework in which it is necessary to move around in creative activity. ${ }^{14}$

\section{Locality of Čajkov}

The Chilejkars are an ethnographic group in Dolné Pohronie, in the region of the traditional culture of Tekov, in the central part of the territory of the former Tekov county. The Chilejkar ethnographic area lies only a few kilometres north of the district town of Levice on the left bank of the River Hron. It consists of the territory of 9 municipalities and their cadastres. ${ }^{15}$

The warm area on the border between the Carpathians and the Pannonian Basin has stimulated a slightly above-average occurrence of lowland culture features and the occurrence

\footnotetext{
${ }^{10}$ DUBSKÁ, Michala and MICHALÍK, Boris. Klasifikácia a evalvácia kultúrneho dedičstva ako predpoklad jeho využitia : Mapovanie a využitel'nost' kultúrnych hodnôt a aktivít. In: Národná osveta : mesačník pre rozvoj miestnej kultúry a záujmovej tvorivosti, 22 (11-12), 2012, pp. 33-36.

${ }^{11}$ LENOVSKÝ, Ladislav et al. Hodnotiaci model kultúrneho potenciálu. Nitra: UKF v Nitre, 2014, p. 14.

12 Theoretically, each historical period left tangible and intangible cultural traces in the studied area (environment).

${ }^{13}$ LENOVSKÝ, Ladislav et al. Hodnotiaci model kultúrneho potenciálu. Nitra: UKF v Nitre, 2014, p. 14.

${ }^{14}$ LUTHER, Daniel. Nehmotné kultúrne dedičstvo (identifikácia a ochrana). In: Zdena Krišková (ed.). Revitalisation of Traditional Culture and Local Identity. Krakow: Towarzystwo Slowaków w Polsce, 2013, pp. 9-22.

${ }^{15}$ Hronské Kl’ačany, Starý Tekov, Vel'ké Kozmálovce, Tlmače, Rybník, Čajkov, Hronské Kosihy, Podlužany, Nová Dedina (originally Tekovská Nová Ves, Opatová and Gondovo)
} 
of some features of mountain culture. It is a West Slovak lowland type of traditional culture with a slightly above-average occurrence of typical phenomena. ${ }^{16}$

This micro-region's identity has been determined by borders, which arose based on the ethnic, religious and cultural differences of its inhabitants from the surrounding environment and mutual similarities within Chilejkars villages, which are still almost homogeneously inhabited by Catholic Slovaks. Boundaries have been defined in various ways with logical consistency and precision. The eastern border is also formed by Slovak villages, but no longer those of Tekov, rather those of Hont. Most of these villages are Lutheran. The southern border is formed by the cadastre of the district town of Levice, a craft, commercial and administrative centre which had already become a centre of industry and urban culture in the Middle Ages. To the west, on the other side of the River Hron, lie other Tekov villages. Until the Second World War, they were inhabited mainly by Hungarians, some of whom were Calvinists. To the north are Tekov, Slovak and Catholic villages that lie behind the ridge of the Štiavnica Mountains and on the other bank of the River Hron. ${ }^{17}$

In the national context, the Chilejkars are representatives of the traditional culture of the Tekov region. They identify themselves and internally differentiate themselves according to the municipality they live in. Within the region, they are most often identified as Chilejkars, especially on occasions of cultural heritage presentation. In the region, the designation Navelers is also known, which has a comical rather than pejorative meaning and is derived from the lowered line of the stem part of the local women's folk clothing (under the belly button), which is unique in Slovakia. ${ }^{18}$ The village of Čajkov is one of the most important representatives of the Chilejkar micro-region and the whole of Tekov. It was one of the 250 research sites of the Ethnographic Atlas of Slovakia project (1971-1974) and the only one in the Chilejkar villages. Also, the village as a whole has been a relatively frequent target of field research by ethnographers and historians, especially from the Tekov Museum in Levice (K. Holbová, J. Dano, K. Gellenová, P. Tesák, K. Sándor). From the end of the 1980s until the turn of the millennium, several cultural-historical or ethnohistorical collection, interpretation or analytical works were created. ${ }^{19}$ Since the 1990s, especially after the year 2000, there has been an apparent interest by the local educational and socio-professional elite in collecting and publishing knowledge about the village of geographical, historical and ethnographic character, which, among other things, has resulted in the publication of a monograph devoted to the village (2001). ${ }^{20}$ Ethnochoreological and ethnomusicological research has also taken place in the micro-region, the results of which are processed and presented as musical and dance work in the repertoires of local folklore groups, regional and Slovak folklore ensembles. A good example is the collection of songs by M. Járek (2001). ${ }^{21}$ Cajkov and the whole Chilejkar microregion is a permanent subject of ethnological research with dozens of professional, scientific and artistic outputs and final theses of university students. These activities have significantly

\footnotetext{
${ }^{16}$ KOVAČEVIČOVÁ, Soňa. XX Kultúrne oblasti a regióny. In: Etnografický atlas Slovenska, Bratislava: VEDA, 1990, pp.102-104.

${ }^{17}$ HOLBOVÁ, Katarína. Čo bolo a je pekné v čilejkárskom Čajkove. In: Jaromír Muráni (ed.). Čajkov spomína a d’akuje 1276-2001. Čajkov: Obecný úrad, 2001, p. 73.

${ }^{18}$ HOLBOVÁ, Katarína. Čilejkári. In: Ján Botík and Peter Slavkovský (eds). Encyklopédia l’udovej kultúry Slovenska I. Bratislava: VEDA 1995 , pp. 75-76.

${ }^{19}$ CHUDOBA, Andrej. Sedemdesiatsedem povesti spod slovenskej brány. Bratislava: Mladé letá, 1974, HLÔŠKA, Milan. Od Tekova vietor veje. Bratislava: Obzor, 1984.

${ }^{20}$ MURÁNI, Jaromír (ed.). Čajkov spomina a d’akuje 1276-2001. Čajkov: Obecný úrad, 2001.

${ }^{21}$ JÁREK, Marián. Zverboval sa Janík. Nitra: Dom Matice slovenskej, 2001.
} 
contributed to the self-awareness and transformation of part of the local traditional culture into the cultural heritage and its current use. In addition, the preservation of cultural traditions here is conditioned by conformity, conservatism and a relatively closed society with strong local patriotism.

The sources of livelihood that the local population can produce through culture and under the influence of the surrounding geographical conditions determine the population's size. A lack of resources reduces the population, birth rate and immigration, as mortality and emigration increase, and vice versa. In Čajkov, the population has been relatively stable in a broader historical context (in the last two centuries, about 1000-1300). ${ }^{22}$ Migration movements that would significantly affect the current local society and its culture are represented by emigration to America and Western Europe. Compared to the more impoverished regions of the territory of today's Slovakia, in Čajkov and the Chilejkar micro-region in general, emigration has occurred to a lesser extent. ${ }^{23}$ Instead, local and micro-regional endogamy and job opportunities in the vicinity have eliminated migratory movements. ${ }^{24}$ Here, the phenomenon of immigrants - prindis - is based on a small number of non-local spouses and permanently settled workers. Even today, paradoxically, its "convexity" and reflection on the local population are more related to its uniqueness. Over the last 50 years, the number of Čajkov locals has been steadily declining. From more than 1300 at the beginning of the 1970s, it decreased, especially in the 1970s and 1980s, to approximately 1000 at present. According to the census, in 2011, 97.43\% declared their mother tongue to be Slovak, and $97.53 \%$ of surveyed respondents, i.e., 988 inhabitants, claimed Slovak nationality (further Hungarian 2, Ukrainian 1, others 2, unidentified 20). The Roman Catholic faith comprised 91.21\% (924 inhabitants), then the Evangelical Church of the Augsburg Confession 4, Greek Catholic 1, Reformed Church - Calvinists 1, Orthodox 2, Jewish 1, other 1, non-religious 31, unidentified 48. The ratio between men and women was balanced in all age categories; women older than 65 significantly outnumbered men of that age group. ${ }^{25}$

Besides, the character of Čajkov cultural heritage is also clarified by the stratification of employment. In 1910, agriculture was the primary source of livelihood for $89 \%$ of the productive population, while 5\% were in crafts and industry, $1 \%$ in public services and the liberal professions, and 4\% were datallers and domestic servants. ${ }^{26}$ In the second half of the 20 th century, agricultural production was collectivised and mechanised in this purely agrarian area. As an important factor in Čajkov farming until the era of collectivisation and the establishment

\footnotetext{
22 The most significant historical demographic changes are population losses due to cholera epidemics in 1838 (details are not known) and in 1855 (170 people became ill in 48 days and 42 people died, including 21 children), and the deaths of 34 men from Cajkov who fell in the First World War, 8 Jewish residents with families, deported and murdered in Auschwitz, and 5 insurgents killed in German concentration camps during the Second World War. (TESÁK, Peter and VALACHYOVÁ, Mária. Prehl’ad dejín obce Čajkov. In: Jaromír Muráni (ed.). Čajkov spomína a d’akuje 1276-2001. Čajkov: Obecný úrad, 2001, pp. 29-71)

${ }^{23}$ This is about emigration to the USA, Argentina and France at the end of the nineteenth century and in the first half of the twentieth century. (DANO, Ján. Žatva a mlatba v „čilejkárskom“ regióne. In: Karol Sándor and Peter Behula (eds). Jubilejný zbornik. Tekovského múzea v Leviciach. Levice: Tekovské múzeum v Leviciach, 1987, p. 83)

${ }^{24}$ Seasonal workers from central Pohronie regularly came to the village, especially from the poorer villages around Ziar nad Hronom. In the interwar period, about a third of the productive inhabitants of Čajkov went to large estates in Levice and its surroundings seasonally, or to richer farmers as grooms and maids year-round. (DANO, Ján. Žatva a mlatba v „čilejkárskom“ regióne. In: Karol Sándor and Peter Behula (eds), Jubilejný źborník Tekovského múzea v Leviciach. Levice: Tekovské múzeum v Leviciach, 1987, pp. 83-91)

${ }^{25}$ OSR 2020 (http:/ /www.sodbtn.sk/obce/obec_stat_vek.php?kod_obce=502111)

${ }^{26}$ VEREŠÍK, Ján. I Úvodné mapy. In: Etnografický atlas Slovenska. Bratislava: NÚSAV, VEDA, 1990, p. 9.
} 
of the state retail network, the sale of the surplus product took place mainly at the annual fairs and weekly markets in Levice. ${ }^{27}$ In 1950, the United Farmers' cooperative was established in Čajkov. ${ }^{28}$ In addition to agricultural production, animal production also developed here. It had a qualitatively and quantitatively great significance and supra-regional importance in the 1980s.

The textile, engineering, food, chemical, glass and nuclear industries were particularly strong in the region in the third quarter of the twentieth century. They employed thousands of people. ${ }^{29}$ Industrialisation caused changes in the traditional socio-professional structure of Ćajkov, and by intensifying the urbanisation of Levice, the number of its inhabitants declined. In 1970 , only $34 \%$ of productive Čajkov locals worked in agriculture, $2 \%$ in forestry, $3 \%$ in construction, $4 \%$ in transport and communications, $4 \%$ in trade and public catering, 10\% in other sectors and up to $43 \%$ in industry. It was a significant change compared to the $5 \%$ in crafts and industry and $89 \%$ in agriculture in $1910 .^{30}$

Nationwide socio-economic and economic-political changes in Čajkov began in the late 1980s. They have been mainly related to the decline and demise of the United Farmers' cooperative and the resumption of private farming in the form of several self-employed farmers and breeders, as well as the development of private viticulture and winemaking. Job opportunities in companies that have survived the period of transformation, although mainly in a reduced form, or in companies located in the new industrial park in Levice, constitute new conditions for labourers. The phenomenon of commuting has re-emerged, but due to new possibilities of traveling to more distant cities, such as Nitra and Bratislava, emigration, mainly to Western Europe, has also been steadily increasing.

\section{The cultural heritage of $\check{C} a j k o v$ as part of its cultural potential A - Cultural heritage ${ }^{31}$ \\ 1. Disappearance of the breeding of geese for the sale of goose quarters and livers}

The expansion of domestic goose breeding for sale was widespread in Čajkov from the end of the nineteenth century to the end of the second third of the twentieth century. Climate, the presence of a watercourse, demand and, in particular, the acquisition of the ability of farms to

\footnotetext{
${ }^{27}$ At the end of the nineteenth century, 6 fairs and markets were held annually in Levice twice a week. Every first Monday of the month there was a cattle market. For example, in 1903 it sold 1,045 horses, 3,129 cattle, 1,537 sheep and 7,740 pigs. In 1932, 23,000 horses, 3,000 oxen, 4,000 cows and 5,100 young cattle were brought to the market. (SÁNDOR, Karol. Z činnosti Tekovského múzea. Historické mozaika. In: Karol Sándor and Peter Behula (eds). Jubilejný z̧bornik Tekovskébo múzea v Leviciach. Levice: Tekovské múzeum v Leviciach, 1987, pp. 45-46) During the second half of the twentieth century, fairs changed their primary function from economic to social-entertainment. The function of weekly markets has not changed, but rather has become a complement to the increasingly developed retail network.

${ }^{28}$ UHNÁK, Ján. Pol’nohospodárske družstevníctvo. In: Jaromír Muráni (ed.). Čajkov spomína a d’akuje 1276-2001. Čajkov: Obecný úrad, 2001, pp. 146-167.

${ }^{29}$ These are the most important national and international companies at that time: Textile plants V.I. Lenina Levice (Levitex), Slovak Energy Engineering - SES Tlmače, Agrochemical company Levice, Milex Levice, West Slovak poultry plants Levice, West Slovak wineries Levice, Novochema Levice, Cosmetics Levice, Preciosa Tlmače, Nuclear Power Plant Mochovce. For example, SES Tlmače (originally Závody S. M. Kirova n. p.) employed more than 7,000 people in the 1980s (today 500, while the number is decreasing).

${ }^{30}$ VEREŠÍK, Ján. I Úvodné mapy. In: Etnografický atlas Slovenska. Bratislava: NÚSAV, VEDA, 1990, p. 9.

${ }^{31}$ A comprehensive evaluation of cultural heritage within the methodology requires each identified element/phenomenon to find out: state of preservation/functionality, availability/access, method of access, use, users/addressees, meaning/reach.
} 
grow maize in the required quality and quantity as a basic feed ${ }^{32}$ have intensified goose farming in such a way that it started producing a considerable economic income. In Čajkov, goose meat was almost exclusively a selling item and at home only for holiday and festive food. ${ }^{33}$ In the second half of the twentieth century, the purchase of livers by traders was introduced. The breeding of geese for sale here was widespread until the 1970s. Then, after a gradual decline, it completely disappeared in the 1980s. ${ }^{34}$ Currently, geese are kept in only a few households for personal consumption. The original and still well-known tradition of selling roasted goose quarters in the region, especially in the markets and fairs in Levice, is now completely gone.

The last former actors who remember past events are women aged 80 and over. Gellenová's study "Eating and preserving goose meat in the 'Chilejkar' villages in Tekov" from 1992 could provide relevant material in possible revitalisation activities of traditional gastronomy in the locality and micro-region. Today, goose meat is represented minimally at existing events in the village. These mainly serve scones, sour cakes, strudel, perky, párance, venison goulash, pork specialties, lokše with duck or goose livers and, exceptionally and seasonally, also freshly cooked plum jam. Specific events of the type of goose feasts in the old school premises with the oldest residents' participation and comments represent a unique challenge. The addressees of the event can be family members and a wider circle of relatives and friends who regularly participate in current events in Ćajkov. In the village, a still-living tradition is the consumption of a well-fed goose, salted, and baked on a clay baking tray, exclusively served cold with bread. The tradition takes place every year during the harvesting of wine grapes.

\section{Viticulture and winemaking}

In Čajkov, the rural type of viticulture is based on the cultivation of vineyards in its northern part. ${ }^{36}$ It is processed into wine and stored directly in the vineyards in the relevant viticultural buildings. There are currently about 300 of them in Čajkov. Wine and grapes are historically

\footnotetext{
${ }^{32}$ For example, at the beginning of the twentieth century in the autumn, 8-10 thousand goose quarters were sold at one weekly market. (SÁNDOR, Karol. Z činnosti Tekovského múzea. Historické mozaika. In: Karol Sándor and Peter Behula (eds). Jubilejný z̧borník Tekovského múzea v Leviciach. Levice: Tekovské múzeum v Leviciach, 1987, pp. 31-52)

${ }^{33}$ Goose breeding was also associated with a number of superstitions, customs, magical acts and elements of folk medicine focused on mating geese, laying eggs, grazing and treatment, but also on ideas about how the success of goose breeding in women is related to other areas of her life within the family and the local community. (GELLENOVÁ, Katarína. Poverové zvyky pri tradičnom chove husí v „čilejkárskch“ obciach. In: Karol Sándor and Peter Behula (eds). Vlastivedný spravodaj Tekovského múzea v Leviciach. Levice: Tekovské múzeum v Leviciach, 11, 1986, pp. 18-22; and GELLENOVÁ, Katarína. Jedlá a konzervovanie husacieho mäsa v „čilejkárskych“ dedinách v Tekove. In: Vladimír Smetana (ed.). Acta museum tekoviensis Levice. Zbornik Tekovského múzea v Leviciach. Levice: Tekovské múzeum v Leviciach, 1, 1992, pp. 81-86)

${ }^{34}$ Back in the 1970s, many Cajkov houselholds kept 20-30 geese, almost all for sale. In the last phase of breeding geese for sale, the geese were also sold on selected days in front of a bakery in the village. An important aspect of the cessation of goose breeding was the reduction of its profitability (increase in costs and decrease in the price of meat) and, in part, the replacement of feathers by quilts, when the need for feather production ceased.

${ }^{35}$ GELLENOVÁ, Katarína. Jedlá a konzervovanie husacieho mäsa v „čilejkárskych“ dedinách v Tekove. In: Vladimír Smetana (ed.). Acta museum tekoviensis Levice. Zbornike Tekovského múzea v Leviciach. Levice: Tekovské múzeum v Leviciach, 1, 1992, pp. 81-86.

${ }^{36}$ Localities: Deberča, Bubláčka, Báličky, Na rýlovom (Rýlovka), Vínna dolina, Močiarnô (Močiarne), Podhorie, Sádovie, Kruhe, Hodruša, Pod múrama (Na múrach), Pod Kemencom.
} 
important trade items. ${ }^{37}$

Traditional production techniques and inventory are still preserved. Manual processing is practiced mainly by small winegrowers, who make up the most significant part of local winegrowers (approx. 80 winegrowers), manage vineyards with an area of 5 to 30 acres, and produce wine mainly for personal use. The largest winegrowers and vintners cultivate from five to twenty hectares of vineyards and produce tens of thousands of litres of wine (the largest well over a hundred thousand litres). The generational change in the period after the year 2000 did not occur in many wine-growing areas, even if they were more prominent than Cajkov. The vineyards partly disappeared, and the area was urbanised in most places, unlike in Čajkov, where it was rather successful. Approximately half a million litres of bottled or cask wine originating from Čajkov enter commercial networks every year. However, there are also more numerous and smaller vineyards, uncultivated or rented, due to lack of interest on the owner's side or lack of working capacity. Other vineyards are bought by larger winegrowers, or non-local and non-regional buyers, which was until recently highly unusual in Čajkov, difficult for the locals to imagine and perceived as a negative phenomenon.

The current state of the wine-growing settlement in Čajkov provides a plastic picture of vineyard cultivation and wine production in all its developmental stages. Typological, functional, construction-technical and architectural diversity and the preservation of a wide range of buildings (from the historical to present-day ones, from excellently preserved/reconstructed/ maintained to skeletons, remains and fragments), including vineyards, infrastructure and surrounding types of cultural landscape (orchards, forests, pastures, non-forest woody vegetation, watercourses, forest paths and sidewalks) fulfil a recreational and leisure, culturalsocial, historical-cognitive, scientific-documentary and landscape-creating function. ${ }^{38}$ This creates an extraordinary potential for greater use in tourism, emphasising hunting, viticulture, hiking, mushroom picking, conservation, mountain biking, outdoor running, orienteering and cross-country skiing. The current use of this potential is small, at the level of one-day suburban tourism. The reason for this is that accommodation and gastronomic facilities are absent in the locality.

Viticultural equipment, instruments and other artifacts related to the cultivation and processing of the vineyard and the production of wine are collected in the old school building. They are occasionally lent for local and regional events or installed inside and outside the old school building. They are registered and presented as the Vineyard Museum in Čajkov.

\footnotetext{
${ }^{37}$ While at the end of the seventeenth century the cultivation of vineyards in the whole of Tekov fell due to non-harvesting (in the county the total area was only 70 hectares of vineyards), in the eighteenth century the area of vineyards increased intensively (in $1715-157$ hectares, 1746 - already 638 hectares and $1786-754$ hectares). The largest areas within Tekov County were then in Čajkov (65 hectares), Levice (59 hectares) and Rybník (40 hectares). The quality of the wine is also evidenced by the data from 1720 when the price of the shackle (approx. 51 litres) of Čajkov or pond wine was 4 gold coins and of Bratislava was 2.5 gold coins. (SÁNDOR, Karol. Z činnosti Tekovského múzea. Historické mozaika. In: Karol Sándor and Peter Behula (eds). Jubilejný źborník Tekovského múzea v Leviciach. Levice: Tekovské múzeum v Leviciach, 1987, p. 45). At that time, the relatively close, rich and extremely densely populated mining towns were the most important market for wine.

${ }^{38}$ On the typology, mapping, analysis and perspectives of the use and preservation of the cultural landscape with an emphasis on viticulture focuses, CHRASTINA, Peter. Vinohradníctvo a rybnikárstvo v Trenčíne a jeho okolí. In: Historická geografie, 36 (1), 2010, pp. 73-98.
} 


\section{Historical Episode of Emigration for Work (Americans)}

Although the topic of emigration to work overseas only concerns a few families in Čajkov (for example, in 1927, 25 families emigrated), it is a crucial aspect concerning the development of local culture. As in most cases, the most important factor for those who decided to emigrate was the high level of poverty and the effort to improve their economic and social conditions in this way. It was not about general poverty but the stratum of the poorest. At the beginning of migration at the turn of the nineteenth and twentieth centuries, only men left. With the start of the First World War, women joined them. The plan was that after the husband had settled in, his wife and children would follow. This plan was not always fulfilled. Men left for work in America throughout the first half of the twentieth century. Some returned permanently after many years of experience, and others only came for visits during a ten-year or more extended working stay. Often, their original plan to return after a few years changed to a lifelong stay, and a permanent return home became an option only after reaching retirement age to live in a circle and under the care of relatives. During their stay in America, migrants tried to keep in touch with home through letters and postcards. They regularly sent packages to their close relatives or even to the family members of their close relatives, especially at Christmas and Easter. They contained quality fabrics for clothing (brocade, cashmere), ribbons, jewellery, haberdashery, beads, fashion clothing (scarves, towels, shirts, ties), home textiles (curtains, tablecloths). These materials and accessories modified the folk clothing of the Chilejkars and distinguished not only the Chilejkars from others but also members of American families from the rest of the local population. During the working stay, the men also sent home money with which the wife, adult son, brother or some other next of kin bought agricultural land as needed, reconstructed the house or had a new one built, bought livestock or mechanised farming. In other cases, the men did so themselves upon their return. In their absence, relatives took care of the property.

The phenomenon of Americanism caused changes in the local society and its culture. In material culture, it contributed to changes in clothing, housing and modernisation of means of production. In the social field, it caused a change in the previously stable social hierarchy and status of the Čajkov families. These included the vertical upward social mobility of American families and the rapid improvement in their wealth. This often occurred, however, at the cost of family breakdown, with the separation of parents from children, the separation of siblings, property disputes or general alienation.

At present, American history/mythology in Čajkov families is partly handed down as part of the families' cultural heritage - as memories, stories and incidents, or through various artifacts. Among other things, in 2015, the exhibition "Chilejkar Americans - emigration from the 'Chilejkar' micro-region to the USA" was opened in the Tekov Museum (by the authors M. Miškovičová Savová and M. Mikulová) as a result of four years of the collecting and processing of objects from private archives and households of Chilejkar-American families.

In connection with the current migration situation in the European (but also global) context and the need for educational and informational activities in the environment of (not only) children and youth, the use of "domestic-American" issue in a regional context can become a relatively effective tool in getting acquainted with all circumstances, aspects and consequences of migration, emigration, new home building, adaptation, integration, intercultural communication, interethnic relations and processes. The most plastic, most trustworthy and most comprehensible images are created on the example of members of their group. Perceiving past and present migrations (including labour) only as positive processes with an emphasis 
on human rights, freedom, courage, a realisation of dreams and improvement of one's own economic and social situation, the acquisition of new knowledge and skills or language skills is equally as deficient and inaccurate (misleading) as a purposeful pointing out only of negative consequences. Examples of negative consequences are the depopulation of source localities of productive and reproductive age members, problems resulting from mutual differences of immigrants and the local population, a failure to meet expectations and ambitions of both migrants and recipients that arose based on unrealistic, idealised ideas and stereotypes.

\section{Women's costume as the most significant feature}

Women's folk clothing in Cajkov is amongst the most representative in Slovakia. It has undergone major changes over the last 100 years. At first, at the turn of the nineteenth and twentieth centuries, it was a work and holiday clothing type. After the First World War, the originally low-coloured dark clothing changed materially and decoratively. Patches, beads, crepes and ribbons were added. The silhouette of a woman changed (skirts were shortened, petticoats were added, cardboard/paper pads were used). The bonnet already had relatively overemphasised contours at the beginning of the twentieth century, and leather pads - fizier - were used. ${ }^{39}$ Ceremonial clothing (for example, mentieka - a bride's coat) remained conservative. ${ }^{40}$ The penetration of urban women's clothing into Čajkov began after 1945, first by Čajkov girls, later by married women. Traditional clothing was still commonly worn by women in the $1960 \mathrm{~s}^{41}$ In the middle of the twentieth century, the wearing of traditional men's clothing was reduced only to holidays and today to stage clothing within the local theatre and folklore group.

The current representative form of the Chilejkar woman's costume is the most decorated variant, from the middle of the twentieth century. Its majesty is declared by its extraordinary decoration and colour, as well as the tall, richly decorated horned bonnet. Initially, older women's clothing used to be less majestic than the clothing of younger ones, but no less complicated, made of quality materials and precisely crafted. This generational differentiation in Cajkov disappeared with the development of the latest variant of the costume and the passing of the previous generation of costume wearers. The current generation of its wearers, especially during the holidays, still uses a "colourful" variant of the costume, which, according to traditional rules, should be given up after reaching the upper limit of middle age. This has not happened, however, because the younger generation that was supposed to take over this custom no longer wears any costumes. Therefore, the oldest generation of women has chosen this solution, still liking to wear the variant traditionally intended for younger women.

At present, approximately 10-12 of the oldest women, over the age of 80, wear a full traditional costume daily in Cajkov. They wear it exclusively and for life. On the other hand, its use depends on their health conditions as their age, the weight of the clothing and the complicated process of getting dressed constitute considerable challenges. These women precisely know the entire system of traditional women's clothing in Čajkov. Their desire to remain distinct and unique motivates them also to familiarise themselves with the patterns used in the surrounding Chilejkar villages. They know possible and still tolerable combinations of clothing components, colours and decorative elements. Failure to follow these rules in traditional clothing is unacceptable to them and a cause for ridicule and shame. They strictly

\footnotetext{
${ }^{39}$ NOSÁLOOVÁ, Viera. Odievanie. In: Slovensko, L’ud 2. čast’. Bratislava: Obzor, 1975, p. 872.

${ }^{40}$ Ibid., p. 891.

${ }^{41}$ HOLBOVÁ, Katarína. Čo bolo a je pekné v čilejkárskom Čajkove. In: Jaromír Muráni (ed.). Čajkov spomina a d’akuje 1276-2001. Čajkov: Obecný úrad, 2001, p. 77.
} 
distinguish between everyday and festive peasant clothing (hábi), including ceremonial clothing, especially in connection with church holidays and appropriate clothing for services. In some cases, younger women of age 70 years and above also don such garb, but in combinations of traditional clothing (most often skirts, petticoats, and headgear) with newer styles (for example, modern shoes, knitted sweaters). Some of their peers, or women a few years younger, still wore the costume as girls, but decided to "change" after getting married or after their children's births, mainly for practical reasons.

Women who wore the costume every day did not give it up even if they worked outside the village. The relationship of the wearers to their folk costume derives from the belief in its exceptionality, value and uniqueness and from the social status of these women and their families, which they still demonstrate in Čajkov by wearing specific costumes. It serves as a local and social identification. ${ }^{42}$

The current use of the costume in Čajkov, in addition to by the abovementioned women, is tied to a selected group of Čajkov locals and specific opportunities related to traditional events and activities in the village (folklore performances, competitions, parades, annual events et cetera). The costume (often adapted as stage clothing) is used by the local folklore group Dolina, the male singing group Čajkov vincúri, the singing group at the Pensioners' Union, the children's folklore group Klások and the children's cymbalo music Slamienok.

Most members of the middle generation and younger never wore the costume on any occasion. In recent years, it is possible to see efforts to use it at traditional events in the village and individually as part of wedding customs. It is worn during Thanksgiving for the harvest after the vintage, at services in the local church, for a costumed procession through the village, at weddings when a bride is given a "horned" bonnet, or when dressing a husband and wife to be in costume before the trip to the wedding or during the wedding reception after midnight. With such demands, sometimes including the role of the elder, they address the local folklore group Dolina.

Current producers in Čajkov - Lubica Chlebová, Anna Ištóková (they make complete costumes or costumed dolls), Mária Petrovičová a Mária Uhnáková (they specialise only in costumed dolls) - are registered under the name "Chilejkar costume - creative workshop of Ćajkov". They are supported by the project of the Ministry of Culture of the Slovak Republic entitled "Folklore the Soul of Slovakia". Mária Nováková makes embroidery on pruclíky. In addition to the above, Ján Uhnák is also involved in the production of costumed dolls. The local primary school has set up its own "costume corner".

Folk clothing from Čajkov co-creates the ethnographic part of the permanent exhibition of the Tekov Museum in Levice, where it represents one of five clothing micro-regions of the region. In the museum, it is presented on mannequins placed on a podium. Headgear - towels and bonnets - ornaments and jewellery have a separate place in the exhibition. The increased acquisition, scientific research and presentation activities of the Tekov Museum on the theme of the Čilejkár micro-region, including the village of Čajkov, can be observed from the 1970 s. It has been related to the arrival of a strong generation of historians and ethnographers and continues to the present.

Folk clothing forms a significant part of the permanent exhibition of the Municipal Museum in Čakjov. This exhibition is also presented under the name "House of Folk Crafts". In two rooms and part of the corridor, mannequins dressed in men's and women's folk clothing are

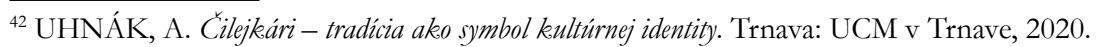


installed, other clothing components are placed on the walls and in period chests of drawers and wardrobes.

\section{Lost ornamentation of poured water patterns}

There are only a few traditional buildings left in Čajkov compared to in some other Chilejkar villages. Several are from the first half of the twentieth century, but those from the second half predominate. Collectivisation and the elimination of farming contributed to the removal of most farm buildings in the urban area. ${ }^{43}$ Traditional architecture is present more in winegrowing settlements than in the village. The ornamentation and decorativeness of the preserved buildings here represent a clear connection between the primary function of decoration and the artistic character of the decoration.

In the collective memory of the oldest inhabitants, in ethnographic works and some monographs on Chilejkar villages, the already extinct watering of patterns is recorded. It originated and was directly linked to urban building and architectural assumptions as characteristics of Chilejkar villages.

On Sundays and other holidays, women, most often girls, poured jugs with one or two openings in a decorative way with spoutings of water and watered the clay floors of rooms, pitches, basements, courtyards, outbuildings or parts of the street in front of the house. The most skilful girls had the task of pouring water on a clay-treated space in the village for a dance party. ${ }^{44}$ Ornamental water pouring was one of the important expressions of the girls' skills and, in general, of the signs of girlhood. During the Sunday walks of the youth, the water pouring patterns were subject to evaluation. Also, before festive, official and important visits, the floor in a house was made wet by "water pouring" as a sign of respect for the visit and, conversely, the visitors evaluated the quality of pouring and the skill of the woman who carried it out. Eight to ten basic patterns, along with their combinations, and variants were used. The same occurred in folk costumes and other embroidered fabrics. ${ }^{45}$

In the middle of the twentieth century, water pouring disappeared with the disappearance of clay floors in houses and gradually with the last generation's maturation. The oldest generation of women who used to engage in this custom still knows the patterns. Water pouring patterns are elaborated in a study by K. Gellenová, published in the Slovak National Museum Ethnography Proceedings in 1984. ${ }^{46}$ They motivated the Parish Office in Starý Tekov (also a village in Cilejkár) and inspired an artistic wireman in the production of the main chandelier in the church in Starý Tekov. ${ }^{47}$ The watering of the patterns is shown in the folklore piece "Na priedomi”, which is in the local folklore group Dolina's repertoire.

Ornaments are a relatively easy-to-use motif in art education, a circle of dexterous hands in a local primary school, or a local kindergarten in a music-movement class in the development

\footnotetext{
${ }^{43}$ TESÁK, Peter and VALACHYOVÁ, Mária. Prehlad dejín obce Čajkov. In: Jaromír Muráni (ed.). Čajkov spomína a d’akuje 1276-2001. Čajkov: Obecný úrad, 2001, pp. 29-71.

${ }^{44}$ HOLBOVÁ, Katarína. Farebnost' a ornamentika v luudovom výtvarnom prejave s príkladmi z regiónu Levického okresu. In: Karol Sándor and Peter Behula (eds). Vlastivedný spravodaj Tekovského múzea v Leviciach. Levice: Tekovské múzeum v Leviciach, 1986, 11, p. 16.

${ }^{45}$ GELLENOVÁ, Katarína. Polievacie vzory z „„̌ilejkárskych“ dedín v okolí Levíc. In: Igor Krištek and Alojz Habovštiak (eds). Zborník SNM Etnografia, Martin: EM SNM, 1984, pp. 132-140.

${ }^{46}$ Ibid.

${ }^{47}$ PÁLENÍK, Ján. Luster zavŕšil vnútornú vybavenost’ farského kostola. 2014. In: Starý Tekov. https://www.starytekov.sk/luster-zavasil-vnutornu-vybavenost-farskeho-kostola-clanok/mid/47673/.html
} 
of children's movement culture and motor skills. ${ }^{48}$ Besides, they are an exciting challenge for graphic design, marketing, branding and other stage use. In connection with the development of scenographic methods and the improvement of technical conditions, the innovative use of poured ornaments in folklore ensembles' environment remains a current and relevant challenge.

\section{Dialect}

The Ćajkov dialect belongs to the Chilejkar dialects. These are the Tekov dialect, the southern group of the Central Slovak dialect and the Tekov Pohronie dialect, which is on the border with the Hontian dialect. It is easily recognisable within the dialects of Slovakia because it is considerably different. At present, the dialect is used as a complex communication system by the oldest and middle generation of Čajkov locals in mutual communication within their kinship, locality and micro-region. Many of them have little knowledge of the dialect or none at all. ${ }^{49}$ The younger of these generations knows the dialect, and partly uses it to communicate with older people at home and in the locality. They no longer use it in mutual communication. Young people and children do not know the dialect (or only partially) or do not use it. Čajkov locals, like other Chilejkars, speak with a specific accent, regardless of whether in dialect or from written language. In addition to the high melody of speech, it is also about terminology, sentence structure, word order and softening. Based on the dialect used only by the oldest inhabitants of the Chilejkars' villages today, they can often determine from which Chilejkar village the speaker is.

Stimulating the interest in their own dialect and the development of communication skills among Čajkov children and youth is a challenge for local elementary schools in teaching language, literature, history, regional education and existing classes: recitation, continual reading. Supporting children and young people's communication in the dialect by creating specific opportunities for its active use following current pedagogical, didactic and methodological procedures is the only way to keep it "alive" in the future..$^{50}$ An example is the primary school

\footnotetext{
${ }^{48}$ About the issue of using elements of traditional culture in the Eastern educational process, see SLOBODOVÁ NOVÁKOVÁ, Katarína, et al. Using the elements of traditional culture in the teaching process from the perspective of ethnopedagogy and ethnology. In: Journal of education culture and society, 12 (2), 2021, pp. 495-504.

${ }^{49}$ The Chilejkar dialect can be spoken almost completely without the use of a written expression or without grammatical accuracy. The dialect is described in MELICHER, Jozef. Krátky slovnik nárečia slovenskébo tekovsko-čilejkárskeho. Bratislava: Print servis, 1996. In addition, the form of the dialect is also recorded in collection publications of verbal and song genres.

${ }^{50}$ Ethnocultural traditions as cultural heritage are effective in the process of revitalising the identity of ethnic collectives. (SLOBODOVÁ NOVÁKOVÁ, Katarína. Study Possibilities of Present-Day Ethnic Revitalization of German Woodsmen in the Little Carpathians. In: Ethnologia Actualis: the Journal of Ethnographical Research, 14 (2), 2014 , pp. 97-108; or SLOBODOVÁ NOVÁKOVÁ, Katarína, et al. Minority languages in Europe in the context of revitalizing activities. In: XLinguae: European Scientific Journal, 11 (3), 2018, pp. 16-27.) In addition to the tangible side, it is most often a language as part of the medium of cultural heritage in the process of linguistic revitalisation of ethnic minorities. (ŠATAVA, Leoš. "New Speakers" in the Context of Minority Languages in Europe and Revitalisation Efforts. In: Národopisná revue, 27 (4), 2017, pp. 323-330; or ŠATAVA, Leoš. New Speakers in the Context of the Minority Languages in Europe and the Revitalisation Efforts = Novi govorci v kontekstu manjšinskih jezikov Evrope in revitalizacijski napori. In: Treatises and Documents $=$ Razprave in gradivo : Journal of Ethnic Studies : revija za narodnostna vprašanja, 82, 2019, pp. 131-151.)
} 
in Liptovská Teplička, where activities and events have been implemented for years in order to preserve the local dialect and implement it in the youngest generation. ${ }^{51}$

\section{B - Cultural organisations and institutions ${ }^{52}$}

There were several associations and organisations in the village in the $1970 \mathrm{~s}$ and $1980 \mathrm{~s} .{ }^{53}$ The current situation has arisen as the result of developments since 1989, especially since the year 2000 when the existing institutions and associations were reorganised and some current interest groups were renewed or established. ${ }^{54}$ The village of Cajkov is a member of the Special Purpose Association of Municipalities of the Chilejkar Region, which was established primarily to prepare and realise sewerage and wastewater treatment, but secondarily also for the general cooperation of member municipalities. ${ }^{55}$ The village is a member of the Regional Association of Towns and Municipalities of Tekov, which consists of 48 members/municipalities.

In the context of maintaining and presenting local cultural traditions, the most important organisations are the Dolina Folklore Group, ${ }^{56}$ Slamienok children's cymbalo music, the singing group of the Slovak Pensioners' Union in Čajkov, the Čajkov Vocational Singing Group and the Association of Vineyards in Ćajkov. The village has established a commission for culture, education and sports, which helps local organisations financially with amounts of 350-550 euros per year. The folklore group Dolina's repertoire consists mainly of scenically processed pieces about the life and calendar cycle customs with an effort to be as authentic as possible. The existence of the mentioned children's and youth platforms is crucial for the future of folklore and folklorism and in a broader context of other related areas of Čajkov cultural heritage. The nearby village of Tlmače houses the Folklore Group Vatra, a representative of Tekov folklore. Active here are young people from the area, interested in higher stylisation and a more sophisticated form of dance (though not exclusively) of regional folklore. Such a connection is an effective tool for maintaining intergenerational continuity, strengthening

\footnotetext{
${ }^{51}$ JÁGEROVÁ, Margita. Diet’a v kontexte rodinného a školského prostredia. In: Zuzana Beňušková et al. Liptovská Teplickea od drubej polovice 20. storočia. Nitra: UKF v Nitre, 2013, pp. 110-184, part Škola ako faktor budovania lokálnej identity, pp. 111-135.

${ }^{52}$ These are various entities that document, preserve, reproduce, make accessible and mediate cultural values. Institutions are entities with a higher degree of formalisation, with which tasks, competencies, long-term activities and a significant proportion of professionals are clearly defined. Organisations are less formally organised groups of people and resources that share common interests and goals. When evaluating cultural organisations and institutions, it is always necessary to find out: general information, membership base, material, administrative and financial background, addressees/consumers, scope and activities.

${ }^{53}$ Socialist Youth Union, Slovak Women's Union, Jednota spotrebné družstvo, Zväzarm, TJ Družstevník Čajkov, Slovak Association of Anti-Fascist Fighters, ČSČK, Slovak Union of Horticulturalists, SZ drobnochovatelov, Association of Cooperative Farmers at JRD, SZ nature conservationists and the Civic Affairs Corps. (TESÁK, Peter, and VALACHYOVÁ, Mária. Prehlad dejín obce Čajkov. In: Jaromír Muráni (ed.). Čajkov spomína a d’akuje 1276-2001. Čajkov: Obecný úrad, 2001, p. 58)

${ }^{54}$ Folklore group Dolina Čajkov, Slamienok - children's cimbalo music, Klások - children’s folklore group, the Association of Vineyards in Čajkov, Union of Pensioners of Slovakia, Association of Christian Seniors, Čajkov Sports Club, Slovak Association of Anti-Fascist Fighters, Local department of the Matica slovenská, Hunting Association „Deberča“" Čajkov, Young conservationists, Civic Association Friends of the Čajkov School, Association of Salesian Collaborators in Slovakia (Basic Information, 2019, https://www.obeccajkov.sk/ zakladne-informacie. html).

${ }^{55}$ Čajkov, Podlužany, Nová Dedina, Hronské Kosihy - construction of sewerage and treatment plant in Podlužany.

${ }^{56}$ Its origin is linked to the trend of establishing such groups in Chilejkar villages (Tekov, Podlužany, Nová Dedina, Rybník and Kozmálovce) after 1989 and their subsequent demise after 2000. At present, they are active only in Tekov and Čajkov.
} 
intergenerational relations within the community and the region, and building a relationship to one's cultural heritage.

\section{Cultural events and cultural products ${ }^{57}$}

Cultural events in Čajkov are mainly annual events of the calendar cycle of local and micro-regional, occasionally regional, significance. Most of them are organised jointly by local organisations and institutions. The most important annual event of regional significance Cajkov Vintage $e^{58}$ - is attended by the municipality, the Association of Vineyards, the folklore group Dolina, the Association of Christian Seniors, part of the Club of the Slovak Pensioners' Union, the local department of the Matica slovenská, the local hunting association and others as needed. Because of the recent coronavirus pandemic, the traditional Regional Wine Tasting and Čajkov Vintage did not occur in 2020. The one-day wine tasting in Čajkov, prepared by the six most important local winemakers, was a suitable substitute. Visitors in a limited number of 10,000 arbitrarily visited the individual factories and tasted the wines.

Other events in the village are intended mainly for members of the associations that organise them or the local population. For example, on Mother's Day, teachers from local primary schools and kindergartens and children's cymbalo music Slamienok prepare a children's programme. Alternatively, the singing group of the Pensioners' Union performs on the same occasion. Domestic pig slaughtering takes place on Shrovetide. The municipality organises it and the Club of the Pensioners' Union presents the piece "Shrovetide before". In May, the local department of the Matica slovenská, the Pensioners' Union and members of the sports club are involved in organising the Liberation Bonfire. Memorial events connected with the war victims, the Slovak National Uprising and the liberation are co-organised by the Union of Anti-Fascist Fighters and the local department of the Matica slovenská. Organised activities include caring for military and abandoned graves in the Cajkov cemetery. In the summer, the local department of the Matica slovenská, together with the Union of Anti-Fascist Fighters, organises day trips.

Local department members of the Matica slovenská have been baking Christmas cookies regularly since 1994 during the Advent season, which they donate as packages to senior citizens. Since 2017, the local department of the Matica slovenska has been organising New Year's Eve "backpacker" entertainment in the local culture house. In addition to the May bonfire, they also organise juniáles in July. It is the traditional ascent to Čajkov Braly, the National Ascent to Sitno, a competition in cooking goulash specialties, including a volleyball tournament.

The local hunting association participates in organising almost every event by providing firewood, meat for goulash or material for the decoration of the premises (Local slaughtering on Shrovetide, May bonfire, annual General Assembly of the Allotment and Urban Society, the annual meeting of the Slovak Pensioners' Union, entertainment for the Association of

\footnotetext{
${ }^{57}$ These are events of both formal and informal type, regular and irregular, in which cultural values are protected, developed, made accessible, presented and used in the broadest sense. These are mainly various festivities, anniversaries, competitions, exhibitions, performances, pilgrimages or festivals. Events need to be seen as an essential part of cultural resources, as they have the ability to attract public attention and can make an economic profit. Their documentation is relatively complex, as larger events often include several smaller accompanying events. During the evaluation, it is necessary to find out about each event and product: general characteristics, procedure, material, financial, administrative conditions, performers/participants, visitor/recipient.

${ }^{58}$ The reason for the first holding of the festivities in 2001 was the celebration of the 725 th anniversary of the first written mention of the village and the presentation of a monograph on the village. Success and positive responses motivated the organisers to make it an annual event.
} 
Parents and Friends of the Primary School and Kindergarten in Čajkov). Since 2001, hunters have been organising the Štefanská party every year. During the vintage, they prepare a hunting exhibition, carry out voluntary service work on Earth Day with primary school pupils, and teach a hunting class at the primary school.

The folklore group Dolina performs several times a year. These are invited Christmas and Shrovetide performances at home or in the surrounding Chilejkar villages, often within the region. Occasionally, its male singers also perform independently (as the Čajkovskí Vincúri singing group). Čajkovskí Vincúri regularly performs at home at the Regional Tasting, or at rag days in the region with the programme "Dancing in the pub", at events organised by the regional tourism organisation of Tekov, at Levice hunting days and in Čajkov vineyards during the St Urban day celebration.

The segment of cultural products generally consists of thematic routes, accompanied cultural-cognitive areas, or the quality system of local products and branding. Given the current situation, it is possible to register the existing but insufficiently used potential in this area.

\section{Cultural infrastructure ${ }^{59}$}

In Čajkov, the cultural infrastructure and its condition are adequate. It consists of premises, equipment, communications, information resources and support infrastructure. It takes into account the general fact that each space can be unique in its character and suitable for different types of activities. ${ }^{60}$ There are specialised facilities in the village, the presence of which is the result of the development of the village since the middle of the twentieth century. Overall, the village has long been one of the more developed (with a primary school, kindergarten, football field, cultural organisation building, cinema with a capacity of 280 seats, library, youth club, offices - dentist, general practitioners and paediatrician - and a House of Mourning). Between 1975 and 1980, a school club and canteen, a grandstand on the football field and modified public spaces were built. In that period, Čajkov won first place in the competition "The Most Beautiful Landscaped Village of the Levice District". All basic infrastructure networks exist in the village (electricity, water, gas, sewerage, internet).

Today, the primary cultural infrastructure of Cajkov consists of the municipal office, the House of Culture, the Vineyard Museum in the old school building - the House of Folk Crafts, the old school complex comprising the building and the adjacent park in the village centre with a podium and benches - an amphitheatre in the wine-growing settlement, the primary school, the kindergarten and the school dining hall. Besides these, larger wine producers have their own purpose-built cultural and social spaces. There are tennis courts, a football field, a gym and a clubhouse in the village. A subject of consideration is the reconstruction and expansion of the old school building, which has an ideal location. The building is also the headquarters of the folklore group Dolina, but its potential is much greater. Discussion relates to the use

\footnotetext{
${ }^{59}$ It consists of cultural spaces and facilities, as well as organisational and information background and other conditions and assumptions. These are premises and facilities enabling the preparation, implementation and presentation of cultural activities. The quality, scope, level, equipment, ownership and condition of these facilities can significantly influence (stimulate and limit) cultural events and thus influence the passive and active participation of the population in the development of culture. Then there are the tools, mechanisms and elements that increase the availability of culture in the broadest sense. (ZIMA, Roman, and PAVLÍKOVÁ, Barbara. Marketingová komunikácia kultúrnych pamiatok v Banskej Štiavnici. In: Roman Zima and Lucia Záhumenská (eds). Cestovný ruch v regionálnom rozvoji : źbornik z. konferencie s medżinárodnou účast'ou. Nitra: UKF v Nitre, 2013, pp. 147-159)

${ }^{60}$ When evaluating cultural infrastructure, we are interested in: general characteristics, owner/administrator of the building, availability/access, state of use, conditions of use, recipients/users/consumers.
} 
of attic and other spaces for accommodation and catering services, the complete absence of which is today the biggest obstacle to the development of any multi-day forms of tourism in Ćajkov. All previous activities of the village (building owner) related to the sale of the building were rejected by the municipal council, despite several interested parties and proposals for use.

The most important element of the cultural infrastructure, which preserves the material cultural heritage of the locality and represents the culture of the micro-region, as well as the region, is the building of the old school, where the Municipal Museum is located. The Municipal Museum as an informal platform consists of two components: the House of Folk Crafts and the Viticultural Museum. The House of Folk Crafts was established on the initiative of the Slovak Pensioners' Union in Ćajkov. Its members enacted the utilisation of part of the otherwise unused dilapidated building to collect and install artifacts of the village's traditional culture, which the locals gradually donated. The exhibition aims to show the ways of traditional living and clothing in the locality. It is the result of the work of local enthusiasts. As a second component, the Viticultural Museum has been created and operates on the same principle. It results from an initiative by one of the largest local wine producers and an amateur historian, a retired gynaecologist. In addition to taking care of the accumulated viticultural and wine inventory, he also ensures its accessibility, lending and the occasional presentation.

The Municipal Museum in Čajkov is the result of a nationwide trend of establishing municipal museums, expositions, folk houses and rooms of traditions, which began after the year 2000. Municipalities used mostly abandoned school buildings, built in the interwar period, industrial and economic buildings which had lost their function after the economic transformation after 1989 (disintegration of local agricultural cooperatives and other manufacturing enterprises) or abandoned, dilapidated but valuable objects of traditional construction and architecture. The enthusiasm of local amateurs characterises their acquisition and presentation activities. Naturally, there is usually no scientific research and professional documentation activity. The quality of these museums is enhanced by possible and occasional cooperation with a nearby city, regional or county museum which has the necessary professional staff resources. In the Chilejkar micro-region, municipal museums/folk houses in the villages of Starý Tekov and Rybník also operate in this way.

\section{E. Human resources}

Individual professions in the cultural/creative sector are a specific category of individuals who work professionally (especially as so-called freelancers) or on an amateur basis in the cultural sector. Apart from the most widespread folk producers, artisans and artists in the Slovak environment, these include all other creative and cultural activities and jobs - individual creators and workers, whose activities are focused on the creation, dissemination, development and protection of cultural values. This category also includes important historians, natives, enthusiasts, collectors, teachers, officials and entrepreneurs. They can be creators who are recognised or unrecognised, active or passive, socially recognised or even not yet registered. There may be situations where there is only a tradition without active bearers, which reduces the real potential for their use. ${ }^{61}$

\footnotetext{
${ }^{61}$ When evaluating human resources, it is necessary to obtain the following information: general characteristics, implementation of the activity, conditions for the operation of activities, use of products and services, students/ continuation of activities.
} 
In Čajkov, human resources are represented by event organisers, leading personalities and members of associations, organisations, and institutions, selected teachers of the local joint kindergarten and primary school, folk producers (the aforementioned costume and doll manufacturers) and performers, local artists and enthusiasts (from the field of local history and ethnography), who keep the whole system of cultural life and the potential of the municipality functional and usable for the addressees - themselves, cross-country visitors and the domestic public. Many of them belong to the local socio-professional elite (with a medical, legal or other university degree and a highly qualified profession). In addition, almost all current crafts are represented in the village through local merchants and self-employed persons. The local elite must be composed not only of officials but also of intelligentsia and entrepreneurs, with contacts at the regional, county and national levels.

In Čajkov, there is a system of using the established concept of local cultural heritage through cultural events (several of which are closely connected in terms of organisation and visitors) implemented by human resources structured into local organisations and institutions, which are relatively diverse but have an internal logic. Some events have a 20 -year tradition; others originated and became "traditional" only a few years ago. The Čajkov community of people who are active in the most diverse way within the broader cultural sphere is organised in various ways. Some are in several associations, with memberships and groups that overlap, and others are only in one. An excellent example of situational but stable cooperation is the local pig slaughtering. ${ }^{2}$

The outlined system existing in a municipality with less than 1000 inhabitants reflects the degree of functioning of the local community. It is conditioned by cohesion, hierarchy, the selfconfidence of members and appropriate economic conditions. For seniors, besides routine and tradition, the essential activating element is the social dimension - being socially active means meeting others, spending time with peers and eliminating loneliness. From a psychological and socio-psychological point of view, this is a critical and irreplaceable factor in the case of seniors. It is equally important in the socialisation, education and especially the upbringing of local children and youth.

\section{Conclusion}

Ethnological field research and heuristics as the primary methods of data collection, and the use of the methodology of cultural potential mapping for data analysis and interpretation of knowledge, have answered several important questions:

1. What is the cultural heritage of the studied ethnographic group (on the example of one of the municipalities)?

\footnotetext{
${ }^{62}$ Facebook, Obec Čajkov, 27. 2. 2017: "Local Slaughtering and Shrovetide Celebrations -> Thank you to everyone who helped organize this year's second slaughtering and Shrovetide celebrations in our village. Members of the hunting association p. Miroslav Petrik. and Ladislav Bôzíle as the main killers and p. Lubomir Belfi and Patrik Babinec, as auxiliary killers, willingly processed the piglet for us. They were also assisted by Jozef Nichta, a member of the OZ, Lukáskeo Wiener, a student of the Cajkov Elementary School, and, of course, employees of the municipal office. The cultural program, which diversified this afternoon, featured the youngest kindergartens, children's cimbalo music Slamienok, domestic folklore group Dolina and at the end cheerfully buried the bass of individual folk:lore ensemble Rozmajrín from Podlužany. The slaughtering specialties were delicious and could be enjoyed by anyone who was interested in eating them. Members of municipality council Ing. Peter Uhnak, PharmDr. Jozef Klinčok and Mrs. Emília Nichtová and our friend Martin Foltan helped with the sale. The cabbage soup and roasted meat were perfectly cooked by the chef of the Čajkov primary school, Tonka Martiniková. All goodies with wine were great and a good mood lasted until the late evening." (Municipality Čajkov, 2017, https://www.facebook.com/obeccajkov/posts/1868060366742427/)
} 
This question is answered primarily by the section "The cultural heritage of Ćajkov as part of its cultural potential, A - Cultural heritage", and partly also by the content of other sections about the components of the cultural potential of the municipality.

2. Why is this the cultural heritage, and how did it originate?

The introductory part of the section "Locality of Cajkov" provides answers to this question. It can be stated that the current form of cultural heritage in the village is the result of the life of local people and their ancestors in the given geographical, socio-historical and political-economic conditions. Geographical conditions determined the locals' way of life and thinking, which is transmitted intergenerationally and which we now call traditional/folk culture. Geographical conditions still determine the preservation and presentation of a part of the traditional folk culture: viticulture and winemaking, which is perceived and used as a value - cultural heritage. Socio-historical and economic-political conditions through social, religious, ethnic, historical, economic and political aspects and artistic-aesthetic trends modelled the geographically determined basis of what we now call the cultural heritage of the exemplary community and studied ethnographic group. Concerning the surrounding socio-cultural environment, these aspects were both inclusive and exclusive. In this way, they created and still create the identity of the inhabitants, the municipality and the micro-region (such as farmers, winegrowers and winemakers, local patriots, Catholics, Slovaks, economically strong people, voters of Christian Democratic parties, et cetera).

3. What are the uses and perspectives of cultural heritage in the locality/micro-region?

The answer to this question was mainly answered by the content of the sections on the components of the cultural potential of the municipality (B-E). The incorporation of cultural heritage (as a component of cultural potential, A) into the system of cultural potential (A$\mathrm{E}$ ) has changed its understanding as a descriptive-enumerative historical category of culture towards the understanding of cultural heritage as a process of existence (tradition, extinction, revitalisation, selection, cumulation), originally a living component of traditional culture.

It has turned out that the real existence of cultural heritage is conditioned by the support of all components of cultural potential. If one is absent (completely or concerning a specific element of cultural heritage), the process does not occur, and cultural heritage as a living element disappears (such as the defunct breeding of geese and the sale of roasted goose quarters and livers, or watered patterns). Conversely, if cultural heritage (in the most general sense, or on a specific example of an elementary cultural element) is part of a functioning system (relevant components of categories B-E), it continues to exist (such as dialect and folklore, folk clothing, viticulture). As a cultural potential, cultural heritage can become cultural capital and commodification as a cultural product by appropriate management. Its consumption will generate a profit (for example, the economic profit of winegrowers, emotional profit of participants in traditional events, or visitors to folklore ensembles or singers, social profit of members of associations, pensioners, children, villagers, meetings of relatives).

The output of the mapping is the creation of a knowledge/information base (database). In practice, access to data on a unified communication portal, the use of open-source resources, GPS, and the creation of web maps, applications et cetera have proved successful. Creating spatial maps of cultural content (spatial cultural mapping) also makes it possible to recognise how the individual resources are distributed, where they are clustered and where the so-called cultural gaps are situated. Cultural mapping is the starting point for cultural policy and the effectiveness of local cultural planning. It helps to create and strengthen a knowledge-based 
society, but especially a future society of the creative age and creative economy. The mapping of cultural potential directly and indirectly increases the (physical, emotional and intellectual) availability of culture and access to cultural content, not only in communicating this information but also in creating and participating in the creation of cultural content. It stimulates the revitalisation of cultural life at the local and regional level, promotes civic engagement and community development, and strengthens local identity. ${ }^{63}$ At the same time, it is a tool for socio-economic development, such as through creating an offer for cultural tourism and a tool for the actual (not only formal) preservation of cultural specifics. ${ }^{64}$

The search for and evaluation of the aspects forming the cultural heritage are mainly the result of an anticipated need and not an actual state. In this way, products are created for consumers. Culture is thus "simulated" and creates possible links in the context of the transferred historical form. The disappearance and replacement of reality cause the creation of stimuli because the possibility of distinguishing between the real and the imaginary is lost. ${ }^{65}$ Nevertheless, who determines what is real and what is imaginary when anthropologists have ample evidence of the subjectivity of this distinction within cultures, even of blurring these boundaries? Although when shifting the interpretation of specific phenomena into simulations, the culture accepts them in a transmitted form and gradually overlaps reality through gradual acquisition. But was this different at any time before?

Constructing or creating a tradition is a common feature of culture. In his thesis on "invented tradition", Hobsbawm considers the creation of traditions to be purposeful and claims that they demonstrate the connection with the past only externally. He describes the constructed tradition as "a set of practices, normally governed by overtly or tacitly accepted rules and of a ritual or symbolic nature, which seek to inculcate certain values and norms of behaviour by repetition, which automatically implies continuity with the past". ${ }^{66}$ After all, in the environment of local communities - to a certain extent (which can change over time) - there is always the demand for tradition, the search for shared history, the return to the "roots" and the effort to identify with the culture of ancestors. By realising a tradition (sometimes even without a significant direct link/continuity), of course, its new bearers sometimes fail to identify its original content and all meanings completely or to fully understand all the contexts in which it has been placed. However, this is not a condition when transitioning from one generation to another.

The unifying elements of culture are the so-called connective structures (cultural memory, collective identity and tradition). As cultural media connect the consciousness of individuals through communication and daily repetitive cultural and social activities, they allow the individual to confront (as well as orientate and anchor!) in the value sphere of the collective. ${ }^{67}$ The separation of the past from the present is a cultural process / social construct. History as

\footnotetext{
${ }^{63}$ KURPAŠ, Michal. Kontexty využívania kultúrneho dedičstva v rurálnom prostredí. In: Roman Zima and Lucia Záhumenská (eds). Cestovný ruch v regionálnom roquoji : zborník z konferencie s medzinárodnou účast’ou. Nitra: UKF v Nitre, 2013, pp. 65-77.

${ }^{64}$ DUBSKÁ, Michala, KURPAŠ, Michal, and ŽABENSKÝ, Marián. Význam strategických a koncepčných dokumentov v rozvoji cestovného ruchu. In: Roman Zima and Lucia Záhumenská (eds). Cestovný ruch v regionálnom rozuoji: zborník z. konferencie s medzinárodnou účast'ou. Nitra: UKF v Nitre, 2013, pp. 27-40.

${ }^{65}$ BAUDRILLARD, Jean. Simulacra and Simulation. Michigan: The University of Michigan, 1994.

${ }^{66}$ HOBSBAWM, Eric. Introduction: Inventing Traditions. In: Eric Hobsbawm and Terence Ranger (eds). The Invention of Tradition. Cambridge, 1983.

${ }^{67}$ SLUŠNÁ, Zuzana, and CHOMOVÁ, Svetlana. Súčasné témy v kultúrnej teórii a praxi. Bratislava: UK v Bratislave, 2015.
} 
a concept is a cultural creation that the community creates and realises. ${ }^{68}$ The revitalisation of cultural patterns presupposes the continuity of the common elements that define it because the dynamics of constructing cultural heritage lie in updating, adapting and (re)interpreting the preserved historically and culturally conditioned knowledge, skills and values of a particular group. It combines preservation and innovation, stability and dynamism, and reproduction and creativity, thus creating a new social meaning that generates identity ${ }^{69}$ However, that is another topic.

\section{Funding}

The study was created as a part of a grant solving task APVV no: 20/0263: Current identification, cultural and revitalisation processes in a minority environment: Slovaks in Argentina and Canada and VEGA no. 1/0383/18: Dynamics and revitalisation of cultural heritage in the context of the transformation of collective identity.

\section{References}

\section{Literature}

ASSMAN, Jan (2001). Kultura a pamèt' : pismo, vapominky a politická identita v rozvinutých kulturách starovék.u. Praha: Prostor. ISBN 80-7260-051-6.

BAUDRILLARD, Jean (1994). Simulacra and Simulation. Michigan: The University of Michigan. ISBN 0472065211.

BESSIÉRE, Jacinthe (1998). Local Development and Heritage: Traditional Food and Cuisine as Tourist Attractions in Rural Areas. In: Sociologia Ruralis, 38 (1), pp. 21-34. ISSN 1467-9523.

DANO, Ján (1987). Žatva a mlatba v „čilejkárskom“ regióne. In: Karol Sándor and Peter Behula (eds). Jubilejný źbornike Tekovského múzea v Leviciach. Levice: Tekovské múzeum v Leviciach, pp. 83-91. ISBN 978-80-88831-17-4.

DUBSKÁ, Michala, KURPAŠ, Michal, and ŽABENSKÝ, Marián (2013). Význam strategických a koncepčných dokumentov $\mathrm{v}$ rozvoji cestovného ruchu. In: Roman Zima and Lucia Záhumenská (eds). Cestovný ruch v regionálnom rozvoji: zborník z konferencie s medzinárodnou účast'ou. Nitra: UKF v Nitre, pp. 27-40. ISBN 978-80-558-0483-5.

DUBSKÁ, Michala, and MICHALÍK, Boris (2012). Klasifikácia a evalvácia kultúrneho dedičstva ako predpoklad jeho využitia: Mapovanie a využitel'nost' kultúrnych hodnôt a aktivít. In: Národná osveta : mesačník pre rozvoj miestnej kultúry a záujmovej tvorivosti, 22 (11-12), pp. 33-36. ISSN 1335-4515.

GAŽOVÁ, Viera (2009). Úvod do kulturológie. Bratislava: FF UK. ISBN 80-7121-315-4.

GELLENOVÁ, Katarína (1992). Jedlá a konzervovanie husacieho mäsa v „čilejkárskych“ dedinách v Tekove. In: Vladimír Smetana (ed.). Acta museum tekoviensis Levice. Zborník Tekovského múzea v Leviciach. Levice: Tekovské múzeum v Leviciach, 1, pp. 81-86. ISBN 978-80-88831-08-2.

\footnotetext{
${ }^{68}$ ASSMAN, Jan. Kultura a pamět’ : písmo, væpomínky a politická identita v rozvinutých kulturách starověku. Praha: Prostor, 2001.

${ }^{69}$ BESSIÉRE, Jacinthe. Local Development and Heritage: Traditional Food and Cuisine as Tourist Attractions in Rural Areas. In: Sociologia Ruralis, 38 (1), 1998, p. 27.
} 
GELLENOVÁ, Katarína (1986). Poverové zvyky pri tradičnom chove husí v „čilejkárskch“ obciach. In: Karol Sándor and Peter Behula (eds). Vlastivedný spravodaj Tekovského múzea v Leviciach. Levice: Tekovské múzeum v Leviciach, 11, pp. 18-22.

GELLENOVÁ, Katarína (1984). Polievacie vzory z „,čilejkárskych“ dedín v okolí Levíc. In: Igor Krištek and Alojz Habovštiak (eds). Zborník SNM Etnografia. Martin: EM SNM, 25, pp. 132-140. ISBN 978-80-8060-421-9.

HHARRISON, Rodney (1983). Heritage. Critical approaches. London and New York: Routledge. ISBN 978-0415591973.

HLÔŠKA, Milan (1984). Od Tekova vietor veje. Bratislava: Obzor. ISBN 978-80-7114-672-8.

HOBSBAWM, Eric (1983). Introduction: Inventing Traditions. In: Eric Hobsbawm and Terence Ranger (eds). The Invention of Tradition. Cambridge: Cambridge University Press. ISBN 9780521437738.

HOLBOVÁ, Katarína (1995). Čilejkári. In: Ján Botík and Peter Slavkovský (eds). Encyklopédia ludovej kultúry Slovenska I. Bratislava: VEDA, pp. 75-76. ISBN 80-224-0234-6.

HOLBOVÁ, Katarína (2001). Čo bolo a je pekné v čilejkárskom Čajkove. In: Jaromír Muráni (ed.). Čajkov spomina a d'akuje 1276-2001. Čajkov: Obecný úrad, pp. 73-97. ISBN 80968633-5-5.

HOLBOVÁ, Katarína (1986). Farebnost' a ornamentika v l’udovom výtvarnom prejave s príkladmi z regiónu Levického okresu. In: Karol Sándor and Peter Behula (eds). Vlastivedný spravodaj Tekovského múzea v Leviciach. Levice: Tekovské múzeum v Leviciach, 11, pp. 13-18.

CHUDOBA, Andrej (1974). Sedemdesiatsedem povestí spod slovenskej brány. Bratislava: Mladé letá.

JÁREK, Marian (2001). Zverboval sa Janík. Nitra: Dom Matice slovenskej. ISBN 80-7090-5861.

CHRASTINA, Peter (2010). Vinohradníctvo a rybnikárstvo v Trenčíne a jeho okolí. In: Historická geografie, 36 (1), pp. 73-98. ISSN 0323-0988.

JANTO, Juraj (2013). Kultúrny a sociálny kapitál lokality ako prostriedok miestneho rozvoja. In: Muzeológia a kultúrne dedičstvo/Museology and Cultural Heritage, 1 (1), pp. 83-99. ISSN 13392204.

JÁGEROVÁ, Margita (2013). Diet'a v kontexte rodinného a školského prostredia. In: Zuzana Beňušková et al. Liptovská Teplička od drubej polovice 20. storočia. Nitra: UKF v Nitre, pp. 110 184. ISBN 978-80-558-0535-1.

KOVAČEVIČOVÁ, Soňa (1990). XX Kultúrne oblasti a regióny. In: Etnografický atlas Slovenska. Bratislava: VEDA, pp.102-104. ISBN 9788022400756.

KRIŠKOVÁ, Zdena (2017). Kultúrne dedičstvo a pamätové inštitúcie. Krakov: Spolok Slovákov v Pol'sku. ISBN 9788374909990.

KRIŠKOVÁ, Zdena (2019). The Use of the Socio-Cultural Potential of Local Societies through the Presentation of Cultural Specificities. In: Slovak Ethnology, 67 (3), pp. 308-323. ISSN 1335-1303.

KURPAŠ, Michal (2013). Kontexty využívania kultúrneho dedičstva v rurálnom prostredí. In: Roman Zima and Lucia Záhumenská (eds). Cestovný ruch v regionálnom rozvoji : zborník z. konferencie s medżinárodnou účast'ou. Nitra: UKF v Nitre, pp. 65-77. ISBN 978-80-558-04835.

LENOVSKÝ, Ladislav et al. (2014). Hodnotiaci model kultúrneho potenciálu. Nitra: UKF v Nitre. ISBN 978-80-558-0726-3. 
LUTHER, Daniel (2013). Nehmotné kultúrne dedičstvo (identifikácia a ochrana). In: Zdena Krišková (ed.). Revitalisation of Traditional Culture and Local Identity. Krakow: Towarzystwo Slowaków w Polsce, pp. 9-22. ISBN 978-83-7490-661-6.

MELICHER, Jozef (1996). Krátky slovník nárečia slovenského tekovsko-čilejkárskeho. Bratislava: Print servis. ISBN 80-88755-25-5.

MURÁNI, Jaromír (ed.) (2001). Čajkov spomina a d’akuje 1276-2001. Čajkov: Obecný úrad. ISBN 80-968633-5-5.

MURÍN, Ivan (2016). Generational transmission in local culture: An exploration of European research drivers in Central Slovakia. In: Anthropological Journal of European Cultures, 25 (2), pp. 57-72. ISSN 1755-2923.

NOSÁL’OVÁ, Viera (1975). Odievanie. In: Slovensko, Lud 2. čast'. Bratislava: Obzor, pp. 861946. ISBN 65-002-75.

SÁNDOR, Karol (1987). Z činnosti Tekovského múzea. Historické mozaika In: Peter Behula et al. Jubilejný źborník Tekovského múzea v Leviciach. Levice: Tekovské múzeum v Leviciach, pp. 31-52. ISBN 978-80-88831-14-3.

SLOBODOVÁ NOVÁKOVÁ, Katarína (2014). Study Possibilities of Present-Day Ethnic Revitalization of German Woodsmen in the Little Carpathians. In: Ethnologia Actualis: the Journal of Ethnographical Research, 14 (2), pp. 97-108. ISSN 1339-7834.

SLOBODOVÁ NOVÁKOVÁ, Katarína, et al. (2018). Minority languages in Europe in the context of revitalizing activities. In: XLinguae: European Scientific Journal, 11 (3), pp. 16-27. ISSN 1337-8384.

SLOBODOVÁ NOVÁKOVÁ, Katarína et al. (2021). Using the elements of traditional culture in the teaching process from the perspective of ethnopedagogy and ethnology. In: Journal of education culture and society, 12 (2), pp. 495-504.

ŠATAVA, Leoš (2017). "New Speakers" in the Context of Minority Languages in Europe and Revitalisation Efforts. In: Národopisná revue, 27 (4), pp. 323-330. ISSN 0862-8351.

ŠATAVA, Leoš (2019). New Speakers in the Context of the Minority Languages in Europe and the Revitalisation Efforts = Novi govorci v kontekstu manjšinskih jezikov Evrope in revitalizacijski napori. In: Treatises and Documents $=$ Razprave in gradivo : Journal of Ethnic Studies : revija za narodnostna uprašanja, 82, pp. 131-151. ISSN 0354-0286.

TESÁK, Peter and VALACHYOVÁ, Mária (2001). Prehl’ad dejín obce Čajkov. In: Jaromír Muráni (ed.). Čajkov spomina a d’akuje 1276-2001. Čajkov: Obecný úrad, pp. 29-71. ISBN 80-968633-5-5.

UHNÁK, Adam (2020). Cillejkári - tradícia ako symbol kultúrnej identity. Trnava: UCM v Trnave. ISBN 978-80-572-0099-4.

UHNÁK, Ján (2001). Pol’nohospodárske družstevníctvo. In: Jaromír Muráni (ed.). Čajkov spomina a d’akuje 1276-2001. Čajkov: Obecný úrad, pp. 146-167. ISBN 80-968633-5-5.

VEREŠÍK, Ján (1990). I. Úvodné mapy. In: Etnografický atlas Slovenska. Bratislava: NÚSAV, VEDA, pp. 2-12 (maps no. 18, 19). ISBN 9788022400756.

SLUŠNÁ, Zuzana, and CHOMOVÁ, Svetlana (2015). Súčasné témy v kultúrnej teórii a praxi. Bratislava: UK v Bratislave. ISBN 978-80-223-4036-6.

SMITH, Laurajane (2006). The Uses of Heritage. London and New York: Routledge. ISBN 9781138580749 . 
ZIMA, Roman, and PAVLÍKOVÁ, Barbara (2013). Marketingová komunikácia kultúrnych pamiatok v Banskej Štiavnici. In: Roman Zima and Lucia Záhumenská (eds). Cestovný ruch $v$ regionálnom rozvoji : zborník z konferencie s medzinárodnou účast'ou. Nitra: UKF v Nitre, pp. 147-159. ISBN 978-80-558-0483-5.

\section{Internet sources}

General Information, accessed May 2020, https://www.obeccajkov.sk/zakladne-informacie. html)

PÁLENÍK, Ján (2014). Luster zavéšil vnútornú vybavenost’ farského kostola. In: Starý Tekov, accessed August 2020, https://www.starytekov.sk/luster-zavasil-vnutornu-vybavenostfarskeho-kostola-clanok/mid/47673/.html

Obce Slovenskej republiky (OSR) 2020, accessed May 2020, http://www.sodbtn.sk/obce/ obec_stat_vek.php?kod_obce $=502111$

Obec Čajkov, accessed August 2020, https://www.facebook.com/obeccajkov/ posts/1868060366742427/ 